\title{
The European Union's Recovery Plan: A Critical Evaluation
}

\begin{abstract}
By Gregory T. Papanikos*
This article reviews the European Union's Recovery Plan to cope with COVID19 by examining two of its main hypotheses. I primarily use Greece as a case study of those who benefit from receiving funds, and in some cases Germany, because it played, and still plays, an instrumental role in promoting this unfounded idea of transferring European taxpayers' money to the hands of national politicians. First, it was alleged that the health situation is improving. Second, the pandemic increases economic divergence between member states. The stylized facts so far do not seem to support either hypothesis. Since the July Summit of the European Council, the epidemiological situation has worsened as measured by deaths and cases. Data on per capita Gross Domestic Product released by the European Commission on 6 May 2020 show an unprecedented for peace years decline in economic growth rates for all 27 member states in 2020. The data estimations also assume a V-shaped recovery for 2021. However, the alleged hypothesis of economic divergence in 2020 and economic convergence in 2021 is not supported by the data themselves. The main conclusion of this study is that the economic impact cannot be fully ascertained if the pandemic is not permanently over and therefore the titanic EU spending of 750 billion euro cannot be based on the stylized economic and epidemiological facts.
\end{abstract}

Keywords: European Union, pandemic, Covid-19, health, growth, public pending, recovery plan, Germany, Greece.

\section{Introduction}

It took God six days to create the heavens and the Earth. This is one day more than the days it took the 27 European Union (EU) Heads of States to create a Recovery or Rescue Plan (RP) from 17 to 21 July 2020. The genesis of the RP is another of those EU (economic) miracles by which the incomes of the future generations of European citizens are taxed to serve the interests of current day politicians ${ }^{1}$.

As a great supporter of representative democracy and the European Union project, I must declare from the outset that I consider these allocations (read

\footnotetext{
"President, Athens Institute for Education and Research, Greece.

${ }^{1}$ After writing this paper, I read a publication (Diamond 2020) which generalized this policy of using tax-payers money to serve the interest of politicians in power and made a persuasive argument that not only money is wasted but the democratic process itself is undermined by authoritarian regimes around the world not excluding the EU countries. These regimes which were elected by "democratic" processes but used the pandemic to suppress freedom of press and independence of the judicial.
} 
misuse) of funds as the necessary cost to maintain (representative) democracy in Europe. It is obvious that I consider these a waste of money, but if their opportunity cost is to avoid another world war, then it makes perfect political rational sense. After all, whenever the EU leaders have difficulties in explaining the rationality of increasing their budget, they use the argument of all arguments: the EU was formed to avoid another world war. Who can oppose to that? Thus, the EU RP aimed, "...to prevent a north-south split" as Financial Times put it at the aftermath of the July EU decision ${ }^{2}$. Another "war" was successfully avoided; the President of the European Council himself was inspired in his youth years by this ideal as proudly posts $\mathrm{it}^{3}$.

With this in mind, I must state that my criticism is not against the RP but to emphasize once again the glory of representative democracy. European people elect the leaders they really deserve who are a mirror-image of the people whom they represent. Thus, there is no surprise that their conclusion of sixty-eight pages of the RP is full of (economic) nonsense but full of rational political realism, i.e., political leaders of the EU member states increase their probability of being reelected in the next national election ${ }^{4}$. Definitely their popularity is a nondecreasing function of the billions of euro allocated to their country. For example, in Greece the government and its political clientele are already bickering about how to "waste" these unexpected external funding which will increase the probability of the current government to be re-elected. Pandemic was an unexpected "dowry" for them because they do not have to apologize for their ridiculous economic plan that first was presented in 2016 by then leader of the Official Opposition Party and now Prime Minister. I have commented on that program revealing not only the lack of basic scientific support of their economic arguments but their inherent contradictions 5 .

Similarly, the purpose of this article is to show the inexistence of any scientific support of the economic part of the RP. This did not come as a surprise to me because representing Greece in one of the five institutions of EU for fourteen years, I had a firsthand experience to test the economic theories that underline this paper. I primarily use Greece as a case study of those who benefit from receiving funds, and in some cases Germany, because it played, and still plays, an instrumental role in promoting this unfounded idea of transferring European taxpayers' money to

\footnotetext{
${ }^{2}$ See https://www.ft.com/content/1fd5785b-5f6f-4175-bae4-214b43a55804.

${ }^{3}$ In his biography (https://www.consilium.europa.eu/en/european-council/president/biography/) the second sentence -after his birthyear and birthplace mentioned which- states the following: "He grew up listening to the stories of his parents and grandparents, who had experienced the devastation of the Second World War and knew how precious peace and reconciliation are. Today he says: 'I have never taken these for granted'" (bold in the original).

${ }^{4} \mathrm{~A}$ reviewer pointed out that this might not be the case with Germany. Of course, the current Chancellor of Germany may not run again for another term but her party will. Thus, the question is whether the RP will benefit her party. As I explain below there are more than COVID-19 in the RP.

${ }^{5}$ See Papanikos (2016). In that program they aimed to increase private investments to 100 billion euro in the next five years in one chapter of their program and in another that their target growth rate was about 4\%. With an annual increase of 20 billion euro in private investment, simple national accounting arithmetic would have shown that the rate of growth would have been more than $10 \%$ per year.
} 
the hands of national politicians. The other 25 countries are split between two groups: those who give and those which receive - and this makes perfect political sense. Public spending and a greater economic role of the state is not something to be condemned as I have explained in my early articles on the theory and practice of public expenditures (see Papanikos 1991, 1990). But public spending should be efficient, effective, democratic (transparent), and externally competitive. I use these terms as they are defined at the textbook level of analysis. I have yet to see an overall project by project multiplier analysis of all EU initiated mammoth public investments or private investments supported by EU using these criteria. A technical report published by the European Commission in 2016 simply recognizes this inability of evaluating investment projects using multiplier analyses.

This paper is organized into six sections including this brief introduction. The next section presents the Recovery Plan, or as sometimes called, the Rescue Plan. The latter represents better the current situation if the sentence is understood to mean that future generations will be taxed to rescue the current generations of politicians in EU. The following section discusses the health impacts of the pandemic as these are measured by the death rate and the number of people infected in EU as whole and per member states. The high variations between member states are ignored by the EU's conclusions of their July summit. In section four of this article evidence is presented to support the EU's hypothesis that the pandemic has led to economic divergence in 2020 using the data released by Economic Commission. The relationship between economic growth and the health impact is examined in section five. Conclusions are given in section six.

\section{The Rescue Package}

According to the conclusions of the European Council, the European Commission will borrow from the capital markets the amount of EUR 750 billion in 2018 prices to be allocated to member states as loans (360 billion) and grants (390 billion) to cope with the current pandemic ${ }^{6}$. The borrowing will end in 2026. Loans will be repaid by the end of 2058 at the latest. In addition, 1,074.3 billion euro will be spent as part of EU's budget, making the total spending 1,824.3 billion for the 2021-2027 period.

As is usual the case in the EU jargon, they invented new names for these two public expenditures: the first is called Next Generation EU (NGEU) and the latter Multiannual Financial Framework (MFF). The European Council's conclusions justify these expenditures as follows:

The COVID-19 crisis presents Europe with a challenge of historic proportions. The EU and its Member States have had to adopt emergency measures to preserve the health of the citizens and prevent a collapse of the economy. We are slowly exiting the acute health crisis. While utmost vigilance is still required on the sanitary situation, the emphasis is now shifting to mitigating the socio-economic damage. This requires an unprecedented effort and an innovative approach, fostering convergence, resilience

\footnotetext{
${ }^{6}$ See https://www.consilium.europa.eu/media/45109/210720-euco-final-conclusions-en.pdf.
} 
and transformation in the European Union. At the request of the Heads of State or Government, the Commission presented at the end of May a very wide-ranging package combining the future Multiannual Financial Framework (MFF) and a specific Recovery effort under Next Generation EU (NGEU)" (European Council 2020).

The Heads of States took for granted two issues which in the scientific jargon can be called testable hypotheses. First, the EU countries, “... are slowly exiting the acute health crisis". Is this the case? What does the evidence show after the July EU meeting? Second, EU expenditures aim at preventing the collapse of the economy by "mitigating the socio-economic damage" which can be achieved by "fostering convergence."

It is not clear what is meant by "convergence" but for all intents and purposes in this paper I interpret it to mean that if the pandemic were left without any EU policy reaction it would have resulted to an unprecedented economic collapse (an obvious observation when the economy is locked down) which will cause an economic divergence between the economies of the member states. This is the causality assumed by the EU document. This assumes that the poor countries of the EU have been hit harder by COVID-19. Why would that be the case? Is this the case? The European Council (2020) document does not answer these two questions and takes for granted that the pandemic has caused an economic divergence.

The two hypotheses are examined here using the available data on the health and economic impact of the pandemic. Health data are available on a daily basis on the number of people infected and died from the disease by country. The number of deaths is arguably a more reliable indicator than cases (i.e., the number of people infected). However, the costs of cases may be different from the ones incurred by deaths, which as an issue is not discussed here. On the other hand, on the 6 of May 2020 the European Commission had estimated that the economic cost of the pandemic which is alleged to be close to one trillion in 2015 prices from EUR 13.3 trillion in 2019 to 12.3 trillion in 2020. The average decline of GDP was estimated to be $7.4 \%$. Also, the estimates of the 2021 data show a Vshaped recovery.

I should make a comment here because many foolishly compare the economic impact of the pandemic in Europe to the economic impact of the Second World War. This is pure economic nonsense for at least two reasons. The Second World War was characterized by a huge destruction of the stock of capital. This is not the case of COVID-19. If nothing else, COVID-19 will increase the stock of capital, both private and public, because the EU spending will be allocated to huge public investment projects throughout the member states, and unless this funding does not crowd out private investments as is the most probable scenario, an overall increase in capital stock is expected. Second, during the Second World War a high proportion of the youth of Europe was killed in the battlefields, decreasing the number of productive workers who would have been available to be used after the war. It might sound cynical, but the COVID-19 economic impact might be positive because it affects disproportionally more the older age group who are no longer productive and they absorb a high amount of public social and health spending. This of course applies only to deaths and not to cases. In a recent study, 
Mallapaty (2020) concluded that "For every 1,000 people infected with the coronavirus who are under the age of 50, almost none will die. For people in their fifties and early sixties, about five will die - more men than women. The risk then climbs steeply as the years accrue. For every 1,000 people in their midseventies or older who are infected, around 116 will die. These are the stark statistics obtained by some of the first detailed studies into the mortality risk for COVID-19." Why would someone who is under 50 pay the high price of a negative growth rate? Or as Reimers and Schleicher (2020) from OECD have pointed out emphasizing the effect of lock down on education and the effect of this on long run growth and youth unemployment, how do policy makers weight these losses? Some policy recommendations have been proposed by García and Weiss (2020).

The aggregate reduction of the growth rate in 2020 hardly constitutes an economic collapse ${ }^{7}$. The EU itself assumes that in 2021 the growth rate of EU will rebound, creating a $\mathrm{V}$-shape type of recovery. This will be achieved with the help of the RP. Member states must prepare their own national plans for the period 2021-2023 which will be approved by the end of this year by the European Commission and then revaluated in 2022. This is the normal notorious bureaucratic procedure of the EU which results in delays and non-absorption. This way, the funding usually comes late and is less than what was originally planned. Both are detrimental to the economic targets adopted by the program but it serves well the goals of national politicians who always blame the Brussels bureaucracy if the absorption does not go relatively well and they want to get all the credit if the absorption goes as planned or even better. In Greece, all structural funds have been delayed and extension was given for increasing the rate of absorption. The alternative where the European Commission itself undertook the design of plans is anathema to national governments because it does not serve their political objectives of "buying votes" for their next national elections.

The European Council (2020) document does not make any reference to the efficient use of the 1.8 trillion euro. But if we assume that 1.8 trillion euro will be spent in the next seven years to make up for the one trillion loss during the pandemic then the multiplier effect of these large public investment projects is less than one, and I guess for some countries like Greece most probably will be negative, i.e., the bad EU public investment funds will crowd out disproportionally good private investments. Of course, these multiplier effects must be larger if one compares the loss not in terms of 2019, but with what would have been the GDP of 2020 if there was no pandemic. A positive growth rate was expected. Unfortunately, the European Council (2020) document does not provide a discussion of these important issues. It seems to me that the efficient and effective use of European taxpayers' money, especially those taxes which are to be paid by the future generations, was never of great concern and therefore an important priority of the EU leaders.

\footnotetext{
${ }^{7}$ This is true for the overall economy but some sectors like the tourism sector in Greece has experienced an almost total collapse as I have demonstrated in Papanikos (2020d).
} 


\section{The Asymmetry of the Health Impact}

Plagues might have severe impacts on the death rate of population. The first well-known plague was the one which struck ancient Athens from 430 to 427 BCE. Thucydides provided an excellent depiction of the plague in his masterpiece of the history of the Peloponnesian War (see Papanikos 2021) which included health and social impact. It is really amazing the similarities of the ancient plague and the COVID-19. The striking conclusion when the two are compared is that contrary to Thucydides' wish and hope, the human race does not learn from its previous historical mistakes and keeps on repeating them. The current pandemic is not an exception as well as previous ones that we have information for and mentioned in the literature previously cited.

I have examined elsewhere the severity of COVID-19 in the 27 EU countries (Papanikos 2020a); not repeated here. This section updates the findings of that paper and adds overall daily data to examine the claim by the European Council's conclusions that EU is, "...exiting the health crisis." This was not examined in my previous study. I start with examining this claim first and then I proceed with the asymmetry hypothesis, i.e., the pandemic's health impact varies considerably between the EU member states.

Table 1 provides descriptive statistics of daily reported deaths and cases in EU countries until the end of August 2020. During this period the average daily death rate was 632 people and the average number of people infected was 8,295. The standard deviation was 932 for the death rate and 8,003 for the number of people infected. In total so far in the EU countries 139,679 people have died from COVID-19 ( $0.031 \%$ of EU population) and $1,833,125$ people have contracted the virus $(0.409 \%$ of total EU population).

Table 1. Descriptive Statistics of Daily Deaths and Cases in EU, January-August 2020

\begin{tabular}{|l|c|c|}
\hline & Deaths & Cases \\
\hline Mean & 632 & 8295 \\
\hline Median & 149 & 5252 \\
\hline Maximum & 4242 & 32963 \\
\hline Minimum & 0 & 0 \\
\hline Std. Dev. & 932 & 8033 \\
\hline Skewness & 1.73 & 1.16 \\
\hline Kurtosis & 5.03 & 3.50 \\
\hline Jarque-Bera & 148 & 52 \\
\hline Probability & 0 & 0 \\
\hline Sum & 139679 & 1833125 \\
\hline Observations & 221 & 221 \\
\hline
\end{tabular}

Source: World Health Organization. Retrieved from: https://COVID-19.who.int/?gclid=EAIaI QobChMItISnjIT76gIVGODtCh1XfQAsEAAYASABEgJK8_D_BwE.

The daily number of deaths is depicted in Figure 1. The first cases in EU arrived in February, it peaked in March, and started to decline since April and May until the EU Council Meeting of 17-20 July of 2020. Thus, the evidence that the 
EU leaders had at hand justified their claim that the EU was exiting the health crisis. However, that was conditional of the economy being locked down. If there is a negative relation between the health impact and the degree to which the economic activity is restricted (locked down), then one may expect an increase in the number of deaths and the number of people infected once the restrictions on economic activities are lifted.

Figure 1. Daily Deaths in EU Countries, January-August 2020

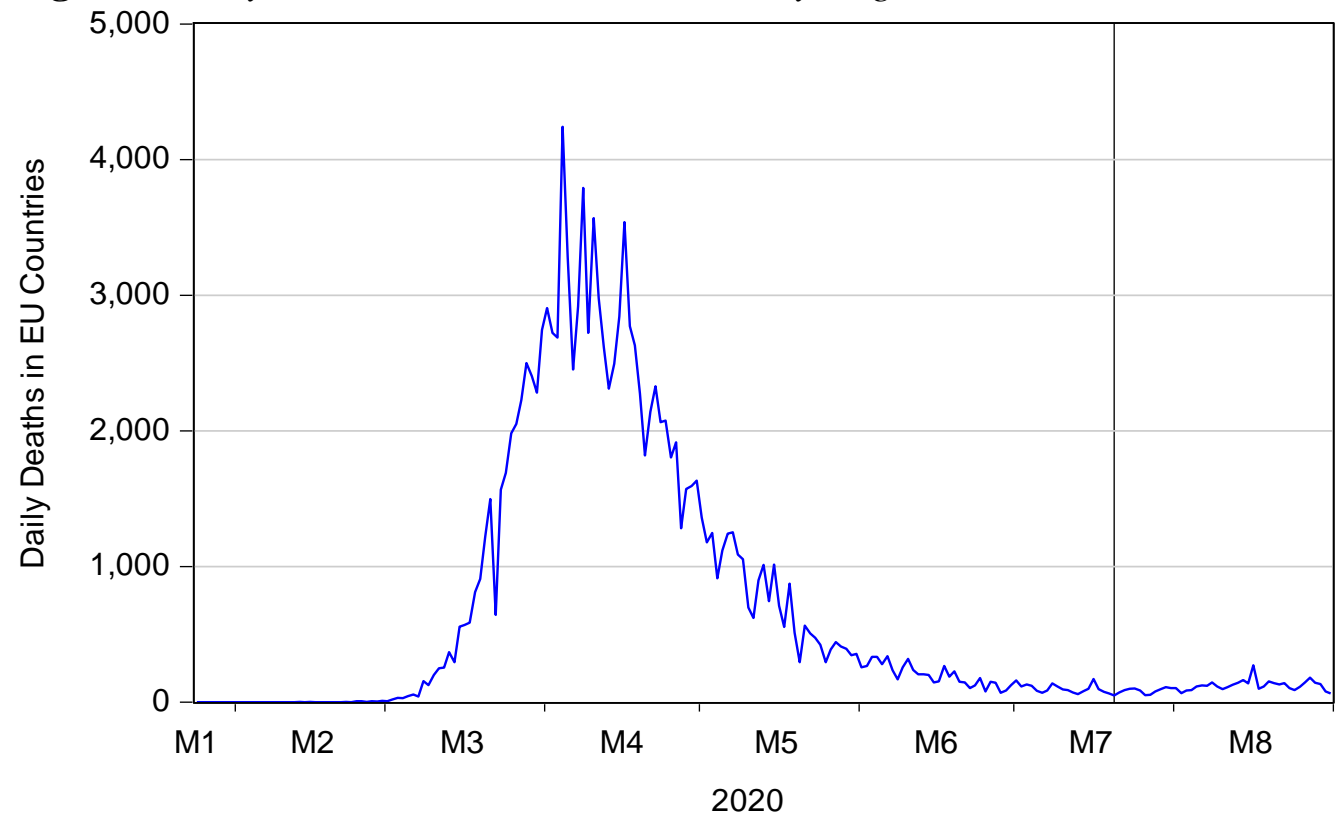

Once the first restrictive measures were lifted, the deaths (and cases which are not reported) started to increase again and this is worrisome for the economy. It implies that opening up the economy will occur at the cost of higher death and case rates. This is shown in Figure 2. The vertical line indicates the date 20 July 2020 which is the date that the summit of EU concluded. By coincidence, on that date the number of deaths was at its minimum after its peak in March-April 2020.

It seems that the pandemic tends to persist despite all of economic and social measures which all EU countries without exception have implemented. The fact that there is an increase in the number of deaths in August 2020 is not a good economic signal for the health impact because it might be related to the slow opening up of the national and international economies especially of the hospitality and travel industries.

I have examined elsewhere the demographics and the health expenditures aspects of the COVID-19 impact in EU countries (see Papanikos 2020b, 2020c). What emerges from these studies is that the health impact varies considerably between the EU member states. A scientific explanation is needed before an economic policy to cope with the pandemic is properly designed and implemented. Such economic policy is based on facts available is missing. Spending tax payer money will not scare away the pandemic; it will simply add to the public deficits and accumulated public debt. 
Figure 2. Daily Deaths in EU Countries, June-August 2020

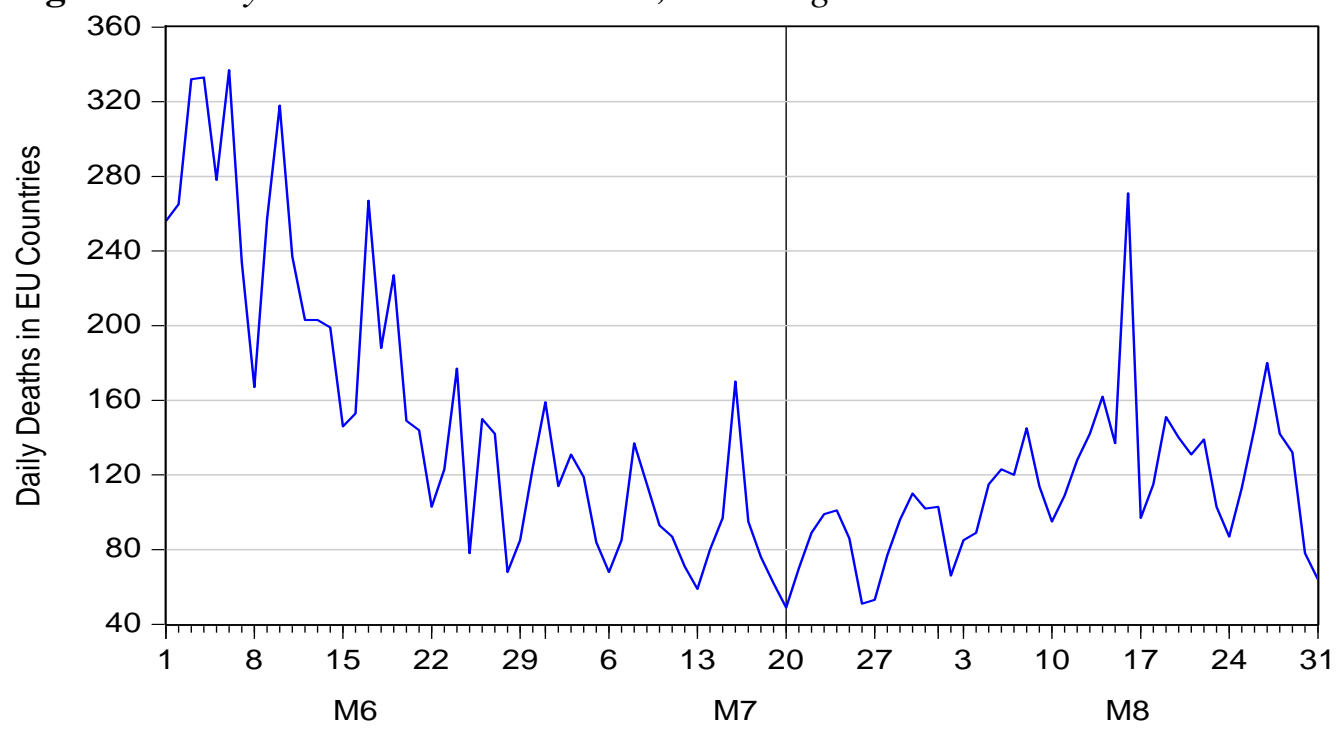

Another issue not mentioned in the conclusions of the EU summit is the large variations in the death rates between the EU countries. Updated data per EU member state to include the August 2020 figures are reported in Table 2. The average death rate (total deaths per million of population) was 194 people and the standard deviation 231 people. The lowest number was observed in Slovakia of six deaths per million people and the highest in Belgium of 857 per million people. What is also of importance is that these variations are independent of the (a) population, (b) geography, (c) size of the country, and (d) per capita GDP. How can one explain the huge difference between France and Germany? France's death rate was four times higher than the Germany's death rate. These variations are ignored by the EU document and my reading of it suggests that the health impact of the pandemic was symmetric.

Table 2. Deaths per Million of Population, January-August 2020

\begin{tabular}{|l|c|c|c|}
\hline Country & Deaths per Million & Country & Deaths per Million \\
\hline Belgium & 857 & Lithuania & 31 \\
\hline Bulgaria & 88 & Luxembourg & 196 \\
\hline Czechia & 40 & Hungary & 63 \\
\hline Denmark & 107 & Malta & 21 \\
\hline Germany & 112 & Netherlands & 356 \\
\hline Estonia & 48 & Austria & 82 \\
\hline Ireland & 359 & Poland & 53 \\
\hline Greece & 25 & Portugal & 177 \\
\hline Spain & 615 & Romania & 185 \\
\hline France & 453 & Slovenia & 61 \\
\hline Croatia & 45 & Slovakia & 6 \\
\hline Italy & 588 & Finland & 61 \\
\hline Cyprus & 24 & Sweden & 561 \\
\hline Latvia & 18 & & 6 \\
\hline Mean & 194 & Minimum & 857 \\
\hline Standard Deviation & 231 & Maximum & \\
\hline
\end{tabular}


This is an important issue; however, it is not analyzed in this paper. One may assume that this is due to policy differences and more specifically, to the timing and the extensiveness of lockdown measures. This might provide an explanation of the severity of the pandemic and the loss of GDP.

Restrictive economic measures such as, a complete lockdown (e.g., closing hotels and banning international travel) decreases the number of deaths and cases, but it also reduces considerably the GDP growth. At some point in the near future, and if the vaccine for COVID-19 is not found soon, then a political decision must be taken between the tradeoff of an open economy and deaths from COVID-19.

This tradeoff was completely ignored in the EU conclusions of the RP which is the focus of this article. Just food for thought: if the growth rate is also related to death rates both in the short and the long run, how then does a policy of locking down the economy completely affect the death rate due to negative economic growth? If these data were available, then policy makers could tradeoff these deaths with the deaths of the COVID-19 when the economy operates without restrictions. This might sound harsh but this is exactly what policy makers are doing. Realizing it or not is not important. It seems that in some countries of the EU the public (especially the youth) does not support anymore the lock down. As mentioned, the risk of coronavirus is zero for the age group under fifty.

\section{Economic Convergence during the Pandemic}

How does a pandemic affect the economy or a group of economies such the EU member states? There is no answer to this question. The economic literature on pandemics is relatively large but no consensus has been reached; studies include among many others the publications of Almond (2006), Bandiera et al. (2018), Barro et al. (2020), Burns et al. (2018), Correia et al. (2020), Eichenbaum et al. (2020), Fan et al. (2018), and Jonas (2013). This literature makes a distinction between short- and long-term effects finding both negative and positive economic effects. It also distinguishes between early and late reactions of governmental policy makers to cope with the pandemic. A brief discussion of this literature is given in my previous paper already mentioned (Papanikos 2020a).

However, I was not able to find anything in this literature which can justify the claim that a pandemic may cause an economic divergence between a group of countries, which for all intents and purposes, belong to a group of relatively affluent countries of the world. Thus, from a theoretical and empirical point of view, EU's claim that the COVID-19 has caused an economic divergence is unfounded. Thus, the justification of spending taxpayers' money, especially of the money of the future generations, is neither based on theory nor on empirical evidence. One may envisage that a relatively poor country may suffer more from a pandemic due to lack of health infrastructure and relatively less government spending on health-related services and infrastructure. Even though, Papanikos (2020c) has found a positive association between GDP and health-related public spending in the EU countries. Higher health spending was not related to COVID19 impact. Overall public health expenditures are not associated with the death 
rates of the member states. However, other factors may explain why this is the case such as the age structure of population.

Despite all the evidence, one of the aims of EU's RP is to mitigate the economic effect of the pandemic by promoting economic convergence. However, the document of the conclusions does not define what is meant by convergence. I assume here that what the leaders of the EU wanted to say is that the pandemic led to economic divergence which the EU extraordinarily expenditures aimed at mending. Thus, the question to be answered is whether the pandemic resulted to economic divergence. Is this the case? No evidence was provided in the document of the conclusions and this is what I want to emphasize in this study. In other words, the leaders of the EU decided to spend additional EUR 750 billion to solve a problem that they did not know existed. This huge amount of taxpayers' money will never solve a problem that most probably does not exit.

The problem is not fall of GDP which is expected with certainty when the EU countries locked down their economies -this says nothing about the economic divergence of the EU member states. However, the EU leaders did have in front of them all of the data to estimate whether in the year 2020 economic divergence occurred and with some heroic assumptions then they could claim that this was due to pandemic. For example, if the poorest countries of EU depend proportionally more on tourism and international travel is banned, then economic divergence is to be expected. However, in this case what is needed is opening up the borders so that tourists can travel. Spending more money will not do it. Finding a vaccine for COVID-19 will suffice.

The European Commission released estimates of the GDP on the 6 May 2020 for 2020 and 2021. These projections included the expected impact of the pandemic. Table 3 shows the rate of growth of real GDP in the current decade of 2010s. Overall the rate of growth of GDP in 2020 is expected to decrease by $7.4 \%$; historically an unprecedented rate but it is also expected to bounce back in 2021 with an increase of $6.1 \%$.

For the purposes of this article, what is of interest is the divergence of economic growth rates as these have been estimated by the official statistical agency of EU (Eurostat) and not the growth rates themselves. From the 27 countries, Greece is expected to be hit the hardest with a sharp GDP decrease of 9.7\%. On the other hand, Poland will register the lowest drop in GDP of $4.3 \%$. These huge differences are left unexplained in the EU document. 
Table 3. GDP Growth in EU Countries, 2011-2021

\begin{tabular}{|c|c|c|c|c|c|c|c|c|c|c|c|}
\hline Country & 2021 & 2020 & 2019 & 2018 & 2017 & 2016 & 2015 & 2014 & 2013 & 2012 & 2011 \\
\hline European Union & 0.061 & -0.074 & 0.015 & 0.021 & 0.027 & 0.021 & 0.023 & 0.016 & -0.001 & -0.007 & 0.018 \\
\hline Belgium & 0.067 & -0.072 & 0.014 & 0.015 & 0.020 & 0.015 & 0.020 & 0.016 & 0.005 & 0.007 & 0.017 \\
\hline Bulgaria & 0.060 & -0.072 & 0.034 & 0.031 & 0.035 & 0.038 & 0.040 & 0.019 & 0.003 & 0.004 & 0.024 \\
\hline Czechia & 0.050 & -0.062 & 0.026 & 0.028 & 0.044 & 0.025 & 0.053 & 0.027 & -0.005 & -0.008 & 0.018 \\
\hline Denmark & 0.051 & -0.059 & 0.024 & 0.024 & 0.020 & 0.032 & 0.023 & 0.016 & 0.009 & 0.002 & 0.013 \\
\hline Germany & 0.059 & -0.065 & 0.006 & 0.015 & 0.025 & 0.022 & 0.017 & 0.022 & 0.004 & 0.004 & 0.039 \\
\hline Estonia & 0.059 & -0.069 & 0.043 & 0.048 & 0.057 & 0.026 & 0.018 & 0.030 & 0.013 & 0.031 & 0.074 \\
\hline Ireland & 0.061 & -0.079 & 0.055 & 0.082 & 0.081 & 0.037 & 0.252 & 0.086 & 0.014 & 0.002 & 0.003 \\
\hline Greece & 0.079 & -0.097 & 0.019 & 0.019 & 0.015 & -0.002 & -0.004 & 0.007 & -0.032 & -0.073 & -0.091 \\
\hline Spain & 0.070 & -0.094 & 0.020 & 0.024 & 0.029 & 0.030 & 0.038 & 0.014 & -0.014 & -0.030 & -0.008 \\
\hline France & 0.074 & -0.082 & 0.013 & 0.017 & 0.023 & 0.011 & 0.011 & 0.010 & 0.006 & 0.003 & 0.022 \\
\hline Croatia & 0.075 & -0.091 & 0.029 & 0.027 & 0.031 & 0.035 & 0.024 & -0.001 & -0.005 & -0.022 & -0.003 \\
\hline Italy & 0.065 & -0.095 & 0.003 & 0.008 & 0.017 & 0.013 & 0.008 & 0.000 & -0.018 & -0.030 & 0.007 \\
\hline Cyprus & 0.061 & -0.074 & 0.032 & 0.041 & 0.044 & 0.067 & 0.034 & -0.019 & -0.066 & -0.034 & 0.004 \\
\hline Latvia & 0.064 & -0.070 & 0.022 & 0.043 & 0.038 & 0.018 & 0.033 & 0.019 & 0.023 & 0.041 & 0.063 \\
\hline Lithuania & 0.074 & -0.079 & 0.039 & 0.036 & 0.042 & 0.026 & 0.020 & 0.035 & 0.036 & 0.038 & 0.060 \\
\hline Luxembourg & 0.057 & -0.054 & 0.023 & 0.031 & 0.018 & 0.046 & 0.043 & 0.043 & 0.037 & -0.004 & 0.025 \\
\hline Hungary & 0.060 & -0.070 & 0.049 & 0.051 & 0.043 & 0.022 & 0.038 & 0.042 & 0.020 & -0.015 & 0.018 \\
\hline Malta & 0.060 & -0.058 & 0.044 & 0.073 & 0.065 & 0.058 & 0.109 & 0.088 & 0.048 & 0.028 & 0.014 \\
\hline Netherlands & 0.050 & -0.068 & 0.018 & 0.026 & 0.029 & 0.022 & 0.020 & 0.014 & -0.001 & -0.010 & 0.016 \\
\hline Austria & 0.050 & -0.055 & 0.016 & 0.024 & 0.025 & 0.021 & 0.010 & 0.007 & 0.000 & 0.007 & 0.029 \\
\hline Poland & 0.041 & -0.043 & 0.041 & 0.053 & 0.049 & 0.031 & 0.038 & 0.033 & 0.014 & 0.016 & 0.050 \\
\hline Portugal & 0.058 & -0.068 & 0.022 & 0.026 & 0.035 & 0.020 & 0.018 & 0.008 & -0.009 & -0.041 & -0.017 \\
\hline Romania & 0.042 & -0.060 & 0.041 & 0.044 & 0.071 & 0.048 & 0.039 & 0.034 & 0.035 & 0.021 & 0.020 \\
\hline Slovenia & 0.067 & -0.070 & 0.024 & 0.041 & 0.048 & 0.031 & 0.022 & 0.028 & -0.010 & -0.026 & 0.009 \\
\hline Slovakia & 0.066 & -0.067 & 0.023 & 0.040 & 0.030 & 0.021 & 0.048 & 0.028 & 0.007 & 0.019 & 0.029 \\
\hline Finland & 0.037 & -0.063 & 0.010 & 0.016 & 0.031 & 0.027 & 0.005 & -0.004 & -0.009 & -0.014 & 0.025 \\
\hline Sweden & 0.043 & -0.061 & 0.012 & 0.022 & 0.024 & 0.024 & 0.044 & 0.027 & 0.011 & -0.006 & 0.031 \\
\hline Standard Deviation & 0.01316 & 0.01334 & 0.01706 & 0.01669 & 0.01420 & 0.04681 & 0.02289 & 0.02256 & 0.02554 & 0.02981 & 0.02724 \\
\hline
\end{tabular}

Source: European Commission (AMECO). [Accessed 22 August 2020], and author's calculations. 
In this paper I only present some stylized facts. Further (econometric) analysis is required which goes beyond the scope of this paper. What is important is whether the pandemic led to a divergence in the rates of growths of the EU countries. The last row of Table 3 shows that this was not the case. The standard deviation of the GDP growth rates of the 27 EU members states is lower in 2020 than in 2019. It seems that as far as the rates of growth of GDP are concerned the EU countries are not expected to have an economic divergence. If anything, they are expected to have a convergence of the rates of growth of GDP.

Economic convergence is usually measured using per capita income, or alternatively a measure of labor productivity or total factor productivity. The purpose here is not to provide a detailed analysis of the issue of economic convergence, but to shed some light on the darkness of the EU conclusions of the RP which provided no evidence for the alleged problem which their policies are to supposedly mend. On the methodology of economic convergence applied to the Greek regional economic convergence see Michelis et al. (2004).

To keep it as simple as possible, I follow Lichtenberg (1994) and assume that the convergence hypothesis can be expressed as the ratio of the log of the variances of per capita GDP in 2019 and 2020:

$$
\text { Convergence }=\left[\operatorname{Var}\left(\operatorname{LnGDPPOP}{ }_{2019}\right)\right] /\left[\operatorname{Var}\left(\operatorname{LnGDPPOP}{ }_{2020}\right)\right]>1
$$

An F-test of the above ratio will demonstrate whether economic convergence is statistically significant. Table 4 presents the per capita GDP of the 27 EU member states using the annual averages of exchange rates for the countries of the EU that are not members of the eurozone. There are large differences in per capita income as these are shown by the standard deviations of GDP per capita. However, what is of interest here is whether this standard deviation has increased or decreased due to the pandemic.

The last row of Table 4 reports the standard deviations of per capita GDP of the EU countries. Before the pandemic there was an upward trend in the standard deviation providing some evidence of non-convergence. In 2020 the standard deviation from 19,598 euro in 2019 decreased to 18,232 euro in 2020 and it is expected to increase to 18,934 in 2021 . According to the numbers reported by the European Commission, the effect of the RP will increase the standard deviation of per capita GDP between the 27-Euro countries. If nothing else, the pandemic seems to promote convergence.

Testing for convergence is testing for differences in the variance of the logarithms of per capita income between two different time periods. Table 5 presents descriptive statistics of the logarithms of the per capita GDP for 2019, 2020 and 2021. The values of interest are the ratios of variances of 2019, 2020 and 2021. If this ratio is greater than one then the convergence hypothesis cannot be rejected. This ratio for the 2019-2020 period is 0.9859 and for the 2020-2021 years is 1.0168. An F-test shows that the ratio of the variances is not statistically different from one. Thus, the stylized facts show neither divergence nor convergence in 2020 . 
Table 4. Per Capita GDP in the EU Countries, 2011-2021

\begin{tabular}{|c|c|c|c|c|c|c|c|c|c|c|c|}
\hline Country-GDPPOP & 2021 & 2020 & 2019 & 2018 & 2017 & 2016 & 2015 & 2014 & 2013 & 2012 & 2011 \\
\hline European Union & 29033 & 27405 & 29642 & 29249 & 28684 & 27969 & 27465 & 26892 & 26513 & 26566 & 26812 \\
\hline Belgium & 37876 & 35680 & 38625 & 38295 & 37917 & 37331 & 36961 & 36435 & 36029 & 36033 & 35992 \\
\hline Bulgaria & 7472 & 6995 & 7480 & 7202 & 6936 & 6652 & 6363 & 6080 & 5933 & 5882 & 5827 \\
\hline Czechia & 17575 & 16999 & 18923 & 18541 & 17625 & 16485 & 15980 & 15058 & 15559 & 16154 & 16674 \\
\hline Denmark & 50804 & 48527 & 51756 & 50866 & 50008 & 49292 & 48050 & 47299 & 46774 & 46613 & 46640 \\
\hline Germany & 38470 & 36400 & 38995 & 38869 & 38400 & 37616 & 37094 & 36776 & 36126 & 36070 & 35987 \\
\hline Estonia & 18242 & 17270 & 18609 & 17913 & 17144 & 16209 & 15824 & 15508 & 15008 & 14753 & 14258 \\
\hline Ireland & 65814 & 62509 & 68287 & 65582 & 61366 & 57381 & 55972 & 45136 & 41870 & 41515 & 41592 \\
\hline Greece & 17144 & 15801 & 17409 & 17056 & 16698 & 16418 & 16381 & 16345 & 16117 & 16537 & 17743 \\
\hline Spain & 24393 & 22917 & 25315 & 25021 & 24550 & 23902 & 23219 & 22340 & 21969 & 22207 & 22899 \\
\hline France & 34228 & 31956 & 34921 & 34366 & 33890 & 33257 & 33019 & 32788 & 32635 & 32616 & 32674 \\
\hline Croatia & 12165 & 11338 & 12693 & 12269 & 11762 & 11184 & 10603 & 10254 & 10296 & 10395 & 10716 \\
\hline Italy & 27546 & 25840 & 28547 & 28422 & 28160 & 27657 & 27257 & 27021 & 27086 & 27734 & 28719 \\
\hline Cyprus & 23275 & 22184 & 24231 & 23751 & 23105 & 22347 & 21031 & 20229 & 20387 & 21766 & 22889 \\
\hline Latvia & 14353 & 13398 & 14371 & 13968 & 13291 & 12688 & 12353 & 11861 & 11553 & 11242 & 10528 \\
\hline Lithuania & 15302 & 14186 & 15389 & 14762 & 14107 & 13345 & 12848 & 12474 & 11948 & 11421 & 10853 \\
\hline Luxembourg & 90708 & 87469 & 94071 & 93876 & 92848 & 93211 & 91440 & 89403 & 87763 & 86872 & 89205 \\
\hline Hungary & 11697 & 11128 & 12867 & 12503 & 12255 & 11631 & 11400 & 10998 & 10946 & 10988 & 11487 \\
\hline Malta & 22808 & 22171 & 24246 & 23993 & 23156 & 22361 & 21620 & 19971 & 18737 & 18128 & 17796 \\
\hline Netherlands & 42079 & 40399 & 43700 & 43205 & 42359 & 41405 & 40732 & 40127 & 39708 & 39876 & 40441 \\
\hline Austria & 41491 & 39699 & 42217 & 41737 & 40948 & 40211 & 39894 & 39889 & 39939 & 40170 & 40078 \\
\hline Poland & 12228 & 11880 & 12948 & 12530 & 11904 & 11066 & 11189 & 10766 & 10383 & 10263 & 10260 \\
\hline Portugal & 19107 & 18057 & 19363 & 18940 & 18424 & 17756 & 17350 & 16974 & 16750 & 16814 & 17454 \\
\hline Romania & 9191 & 8782 & 9438 & 9218 & 8936 & 8439 & 8087 & 7751 & 7510 & 7164 & 7351 \\
\hline Slovenia & 21175 & 19891 & 21448 & 21106 & 20332 & 19406 & 18830 & 18437 & 17960 & 18171 & 18699 \\
\hline Slovakia & 16254 & 15259 & 16376 & 16033 & 15433 & 14998 & 14709 & 14042 & 13680 & 13606 & 13373 \\
\hline Finland & 40292 & 38907 & 41604 & 41241 & 40639 & 39509 & 38570 & 38488 & 38796 & 39330 & 40078 \\
\hline Sweden & 39592 & 38481 & 42363 & 43637 & 45979 & 46304 & 46349 & 46116 & 47672 & 47274 & 46198 \\
\hline Standard Deviation & 18934 & 18232 & 19598 & 19474 & 19219 & 19145 & 18856 & 18154 & 17931 & 17820 & 18090 \\
\hline
\end{tabular}

Source: European Commission (AMECO). [Accessed 22 August 2020], and author's calculations. 
Table 5. Descriptive Statistics of the Logarithms of Per Capita GDP

\begin{tabular}{|l|c|c|c|}
\hline & LOG(GDPPOP19) & LOG(GDPPOP20) & LOG(GDPPOP21) \\
\hline Mean & 10.108 & 10.023 & 10.076 \\
\hline Median & 10.095 & 10.007 & 10.035 \\
\hline Maximum & 11.452 & 11.379 & 11.415 \\
\hline Minimum & 8.920 & 8.853 & 8.919 \\
\hline Range & 2.532 & 2.526 & 2.496 \\
\hline Std. Dev. & 0.613 & 0.617 & 0.612 \\
\hline Variance & $\mathbf{0 . 3 7 6}$ & $\mathbf{0 . 3 8 1}$ & $\mathbf{0 . 3 7 5}$ \\
\hline Skewness & 0.178 & 0.194 & 0.184 \\
\hline Kurtosis & 2.454 & 2.415 & 2.416 \\
\hline Jarque-Bera & 0.478 & 0.555 & 0.536 \\
\hline Probability & 0.787 & 0.758 & 0.765 \\
\hline
\end{tabular}

Source: Author's calculations.

Thus, the conclusion which emerges from the above brief analysis of the statistical data provided by the European Commission is that the pandemic did not affect the convergence of the economies of the $27 \mathrm{EU}$ member countries. The aim of the RP to mend a gap that was never opened makes no sense and the 2021 data show that the planned expenditures will not affect the convergence. However, according to the estimates of EU, these expenditures are expected to have a large effect on economic growth of EU's GDP as is shown in Table 3.

\section{The Economic and Health Impact of the Pandemic Compared}

How can one explain the high variations in the growth rates of 2020 as these are reported by the European Commission? ${ }^{8}$ One possible explanation is that the high variation of the COVID-19 impact on death rates and the number of people infected had a diverse impact on economic growth. It was shown above that COVID-19 had an asymmetric health effect in the EU countries.

The process is important here. Unfortunately, the EU idea of a common action to face a common problem did work out as one would have expected. On the contrary, COVID-19 revealed once again that there is no such thing as a common European policy. Each country of the EU implemented its own policies to cope with the COVID-19 impact at different time periods. This is not an argument in favor of a common policy but to emphasize the contradiction between the EU summit which aimed at coordinating a common policy and the practice of each country or each region within each country. In Germany, Italy and Greece policies were determined at subnational level as well. On the other hand, EU common policies to fight the pandemic may not be sufficient because this is a global phenomenon and should be dealt with international collaboration. Institutions such as the World Health Organization (WHO) and World Trade

${ }^{8}$ I have examined in Papanikos (2015) the growth rates differences between the EU member states. As argued there the reason was the misalignment of the real effective exchange rate which benefited Germany and harmed the Greek economy. 
Organization (WTO) have failed to play a leading role either because their role have been undermined as suggested by Goldin (2020) but it might be the result of their own incapacity in dealing with world crises.

Figure 3. Growth and Death Rates in the EU Compared

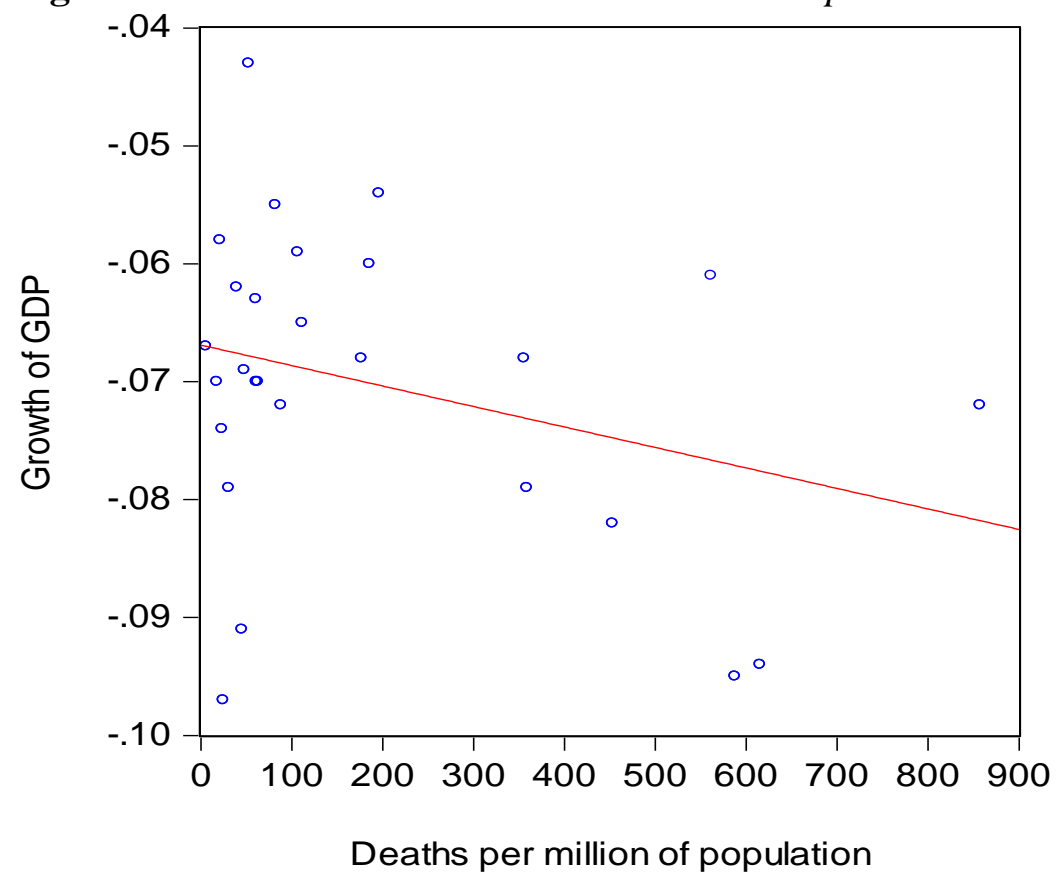

The most important of all was the timing of shutting down economic activity the argument goes as follows. Countries which locked down their economies earlier had lower death rates than countries which reacted late when the disease had already spread to society at large. The cost paid by those countries which locked down their economies earlier than others would have had a higher loss of output. On the other hand, those which locked their economies late would have gained in output growth but they would have lost in terms of death rates. One, then, should expect a positive relation between growth rates and death rates. Higher growth rates relative to other countries in the EU were obtained at the cost of higher death rates.

Figure 3 is a scatter diagram between the growth and death rates of the $27 \mathrm{EU}$ member states. Contrary to what was stated above, the relationship is negative and is shown by the linear regression line. Higher growth rates are associated with lower death rates, but the dispersion is so high that no reliable conclusion can be drawn.

It seems that the process by which the COVID-19 affects the economies of EU countries is not the same. Great variations exist which need further study at the individual country or even regional level. If the process is different, then the policy design should be tailored to the needs of each country or region. This may require more than spending EU money. 


\section{Conclusions}

This paper examined two claims made by the EU's summit in July 2020 to justify a spree of public spending to be financed by the future generations of Europe's taxpayers. These mass spending serves the needs of the current politicians of the governments of the member states which is supported by anecdotal evidence from Greece and Italy but a future research may look at this relationship more carefully. The first claim made in the document at the conclusion of the July meeting was that the EU is slowly exiting the pandemic. This was true at the time the decision was taken (20 July 2020). This was conditional on the severe measures taken to stop the spread of the disease which included a complete lockdown of the economies. Once these measures were lifted the number of deaths and cases started to rise again.

The second claim made by EU leaders is that the economic impact of the pandemic was not only a sharp decrease in the rate of growth of GDP but an increase in the economic divergence of the member states economies. Based on the estimates of GDP declines made by EU itself, the empirical evidence does not support their claim of economic divergence in 2020 and economic convergence of 2021.

The economic irrationality of EU spending in terms of the growth impacts can only be explained if the rationality of political decision making is taken into consideration. The COVID-19 health and economic impact is used as an excuse for the national governments to spend more to increase their probability of being re-elected in the next national elections. This is true for the countries which will receive the money (e.g., Greece) but even the donors (e.g., Germany) may benefit if what was at stake was the political integrity of EU itself.

From this point of view, the RP plan is a good excuse to rescue national politicians of the EU member states. This is a subject of future research as data on the probability of being reelected at the national level become available. Some public opinion polls do suggest this is definitely the case for Greece and Italy which are both great waste outlets of EU taxpayers' money.

It is true that in Germany the RP is not very popular and this is understandable. However, as explained by a Policy Brief of the European Council of Foreign Affairs prepared by Puglierin and Franke (2020), the RP might be a prelude to a wider geopolitical collaboration between Germany and France in fostering a common foreign and security policy. As they put it "On 1 July, Germany took on the presidency of the Council of the EU. Some observers have labelled it as the most important presidency in the EU's history, a make-or-break moment." And a few lines below "If there was a beauty contest for EU coalition-building, Germany would be its winner." Based on survey data of all 27 EU members, Germany is considered the most important and reliable member state which can be trusted to reach a consensus at the EU level. As Puglierin and Franke (2020) state, "The survey shows that, in almost all policy areas, German respondents have a strong preference for making decisions based on a consensus between all member states and are reluctant to embrace differentiated integration - to work with only some 
EU members - as they fear that this could divide the union". Thus, from a political point of view, Germans are willing to pay the price of RP, lest the EU is divided.

\section{References}

Almond D (2006) Is the 1918 influenza pandemic over? Long-term effect of in utero influenza exposure in the post-1940 U.S. population. Journal of Political Economy 114(4): 672-712.

Bandiera O, Buehren N, Goldstein M, Rasul I, Smurra A (2018) The economic lives of young women in the time of Ebola: lessons from an empowerment program. Washington, DC: World Bank.

Barro R-J, Ursua J-F, Weng J (2020) The coronavirus and the great influenza epidemic lessons from the "Spanish flu" for the coronavirus's potential effects on mortality and economic activity. AEI Economic Policy Working Paper Series. American Enterprise Institute.

Brainerd E, Siegler M (2003) The economic effects of the 1918 influenza epidemic. Discussion Paper Series 3791. Centre for Economic Policy Research.

Burns A, Mensbrugghe D, Timmer H (2008) Evaluating the economic consequences of avian influenza. Working Paper 47417. Washington, DC: World Bank.

Correia S, Luck S, Verner E (2020) Pandemics depress the economy, public health interventions do not: evidence from the 1918 flu. SSRN (Jun).

Diamond L (2020) Democracy versus the pandemic: the coronavirus is emboldening autocrats the world over. Foreign Affairs, 13 June.

Eichenbaum M-S, Rebelo S, Trabandt M (2020) The macroeconomics of epidemics. NBER Working Paper 26882. National Bureau of Economic Research.

European Commission (2016) Measuring the impact of structural and cohesion funds using regression discontinuity design in EU27 in the period 1994-2011. European Commission.

European Council (2020) Special meeting of the European Council (17, 18, 19, 20 and 21 July 2020) - Conclusions. European Council.

Fan V-Y, Jamison DT, Summers L-H (2018) The loss from pandemic influenza risk. In Disease Control Priorities: Improving Health and Reducing Poverty, chapter 18, 347-358. World Bank.

García E, Weiss E (2020) COVID-19 and student performance, equity, and U.S. education policy: lessons from pre-pandemic research to inform relief, recovery, and rebuilding. Economic Policy Institute.

Goldin I (2020) Rethinking global resilience. International Monetary Fund.

Jonas O-B (2013) Pandemic risk. World Development Report Background Paper. Washington, DC: World Bank.

Lichtenberg F-R (1994) Testing the convergence hypothesis. The Review of Economics and Statistics 76(3): 576-579.

Mallapaty S (2020) The coronavirus is most deadly if you are older and male - New data reveal the risks. Nature, 28 August.

Michelis L, Papadopoulos AP, Papanikos GT (2004) Regional convergence in Greece in the 1980s: an econometric investigation. Applied Economics 36(8): 881-888.

Papanikos GT (1990) A macroeconomic theory of public production. Public Enterprises 10(3-4): 281-290. 
Papanikos GT (1991) A small macroeconometric model with direct government intervention on the demand and the supply side: the Canadian experience in the 1970s and in the 1980s. Economic Modelling 8(2): 187-200.

Papanikos GT (2015) The real exchange rate of euro and Greek economic growth. Journal of Economic Asymmetries 12(2): 100-109.

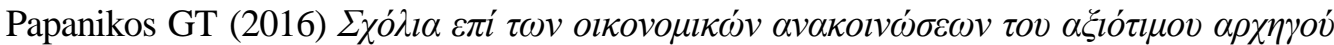

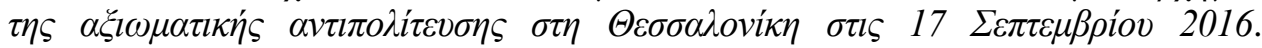
(Comments on the economic announcements of the honorable leader of the official opposition). Mimeo.

Papanikos GT (2020a) The Economic impact of the 2020 pandemic in the European Union. Mimeo.

Papanikos GT (2020b) The demographics of COVID-19 in the European Union. Athens Journal of Social Sciences 7(4): 279-290.

Papanikos GT (2020c) Do national health expenditures matter for the COVID-19? Evidence from the European Union. Mimeo.

Papanikos GT (2020d) The impact of the COVID-19 pandemic on Greek tourism. Athens Journal of Tourism 7(2): 87-100.

Papanikos GT (2021) Thucydides and the synchronous pandemic. Athens Journal of History 7(1): 71-94.

Puglierin J, Franke UE (2020) The big engine that might: how France and Germany can build a geopolitical Europe. Policy Brief. European Council on Foreign Relations.

Reimers FM, Schleicher A (2020) A framework to guide an education response to the COVID-19. Paris: OECD. 